\title{
Marconi’s Legacy: National Sovereignty Claims in Radio
}

\author{
by Robert Horvitz \\ Open Spectrum Foundation \\ Email: bob@openspectrum.info \\ 1st COMMUNIA Workshop on "Technology and the Public Domain" \\ NEXA Center for Internet and Society, Politecnico di Torino
}

18 January 2008

\begin{abstract}
Since early in the 20th century, national governments have asserted sovereignty over the electromagnetic spectrum. These assertions were initially embraced as a way to control the monopolistic ambitions and offensive business practices of the Marconi Wireless Telegraph Company. They are still the basis of radio regulation. However, as wireless communication moves to higher and higher frequencies - into the range of infrared (heat) and "free space optics" (light) - it is becoming obvious that claiming sovereignty over radio frequencies makes no more sense than claiming sovereignty over colors of the rainbow. Is radio legally different from light? If not, might we someday need government permission to use certain colors of light for certain purposes, as with the invisible colors of radio?
\end{abstract}

\section{Introduction}

Today I want to challenge a principle which has been the basis of radio regulation for about a century. Twenty minutes from now, I hope you will agree with me that some of its claims are so outrageous that they deserve to be challenged. And if you agree, then maybe we can start a discussion about what other approaches might be more appropriate.

The principle I want to challenge is the claim by national governments of sovereignty over all radio waves within their territorial boundaries and transmitted from vehicles registered in their country.

Since early in the 20th century, claims of national sovereignty over radio have been made by virtually every country's government. [1] Such claims are legitimized by the international treaty which establishes the framework for radio regulation at the national level. [2] These sovereignty claims are enshrined in laws, cited in court decisions and implemented in millions of licenses. So challenging the principle could have serious repercussions - at least I hope it will.

This challenge is possible because governments actually have about as much sovereignty over radio waves as they have over the colors of the rainbow. Theirs is an overreach exceeding even that of the lawmakers in the US state of Indiana, who in 1897 declared "a new mathematical truth": that the numerical value of $\pi$ will be 3.2 in Indiana instead of what it is everywhere else: $3.14159 \ldots$ That actually happened, though some legislators recognized it as a joke. [3] However, sovereignty claims in radio are no joke and, after a century, they are deeply ingrained. Unless they are confronted and weakened now they will expand and in the next few years countries may indeed start trying to regulate the colors of the rainbow. 
Now, I am not a lawyer or a politician, so I am probably unfamiliar with aspects of national sovereignty that make applying this concept to electromagnetism less absurd. On the other hand I know why it did not seem absurd a century ago, and I will try to give a fair account of the circumstances back then.

However, I will also argue that our perspective on radio sovereignty can and must be different today, because we have other ways to manage this resource now, and because the invocation of state sovereignty had less to do with the innate properties of the medium than with the geopolitical situation when radio came into wide use, and that situation has changed.

\section{What is "radio"?}

First, let's be clear about what radio is: waves of electromagnetism moving through space. Heat, light and radio are all the same "stuff". These familiar words correspond to different rates of energy vibration and thus different parts of the spectrum. Frequencies a bit lower than light are called "heat." Frequencies lower than heat are called "radio."

Physicists tell us that electromagnetic waves cannot be separated from space. They are "excitations of vacuum," as Henning Genz put it: "We can loosely compare the vacuum to a farmer's field of wheat that is swaying in the wind, and the particles [of energy and matter found in it] to the wave patterns excited by the wind on its surface." [4]

So some of the absurdity of claiming sovereignty over radio comes from the metaabsurdity of claiming sovereignty over a vacuum. That may sound like "The Emperor's New Clothes" but it emerged as an important issue when the human exploration of outer space began in the 1950s. Still, projections of national sovereignty into the cosmos are conceptually fragile so political support soon shifted toward the commercialization of space ventures, on the one hand, and a counter-notion, defining space resources as the "common heritage of mankind." [5] Most people associate the latter phrase with the UN Convention on the Law of the Sea, but in fact it first gained traction in an extraterrestrial context. [6] Some likewise argue that the radio spectrum should be treated as the "common heritage of mankind" [7] while others want to "property-ize" it. [8] 
We will return to that bifurcation later. For now it is sufficient to note that the distinction between radio and heat is very "soft." (Consider microwaves: they are used for cooking and for communication, so they have the characteristics of both radio and heat.) The "softness" of the heat/radio distinction made it easy for regulators and governments gradually to shift the legal boundary to higher frequencies and thus expand their authority over more of the spectrum. This is now being tried at the boundary between heat and light - which is not so soft.

In 2000 the World Radiocommunication Conference (WRC) changed the definition of radio used by the International Telecommunication Union, raising the upper frequency limit from $400 \mathrm{GHz}$ to $1000 \mathrm{GHz}$. [9] The next WRC in 2003 raised it again, to 3000 $\mathrm{GHz}$, which is quite far into the zone that most people would consider heat. [10] And in November 2007, the latest WRC decided that the ITU should start exploring the need for procedures to regulate "free-space" optical frequencies above $3000 \mathrm{GHz}$. [11] This is the realm of visible light.

Because radio, heat and light form a continuum, and because national sovereignty is an established principle in radio, if regulators keep enlarging the definition of radio, someday you might need a license to operate a laser, desk-lamp or toaster - or perhaps even wear red socks. Admittedly, that is a "worst-case" scenario. But it is a logical extension of the kind of state control we accept as normal and necessary for radio. The legal precedents and bureaucratic apparatus are already in place.

Figure 2. RONJA - Karel Kulhavy has developed a remarkably low-cost technology called RONJA (Reasonable Optical Near Joint Access),. Based on the red LEDs normally used as brake lights in cars - these cost about $\$ 1$ each - RONJA can send digital data at $10 \mathrm{MB} / \mathrm{sec}$ to distances of 1.4 $\mathrm{km}$. Dozens of community wireless networks now use RONJA as their "backbone." This technology could not have developed if light was subject to the same kind of rules and authorisation procedures as radio. See http://ronja.twibright.com/

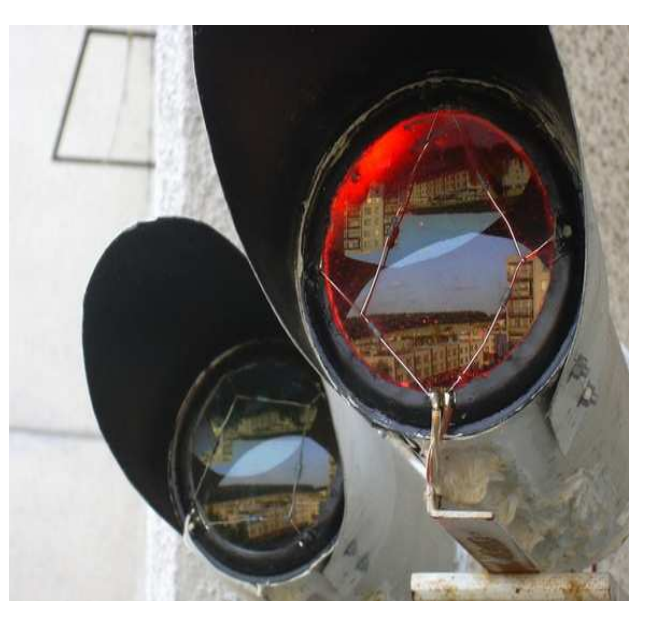

\section{What is "sovereignty"?}

Let us also try to be clear about what "sovereignty" is. Wikipedia defines it as "the exclusive right to complete control over an area of governance... The key element of sovereignty in the legalistic sense is that of exclusivity of jurisdiction..." [12] When a decision is made by a sovereign, there is no higher authority which can overrule it.

Wikipedia also notes that "the Peace of Westphalia in 1648 established the notion of territorial sovereignty as a doctrine of noninterference in the affairs of other nations." [13] As it happens, noninterference is an important issue in radio, too. Radio licenses 
not only confer the right to use a certain set of frequencies, they confer the right to use those frequencies without interference from other transmitters. So a radio license resembles a temporary grant of sovereignty. One might even argue that states assert sovereignty over the radio spectrum so they can delegate frequency rights to their citizens, since "no one can give away what he does not himself possess," as Hugo Grotius put it in Mare Liberum [Freedom of the Seas] (1633). [14]

That suggests no one would have the right to use radio if their sovereign had not previously gained the right for them - a suggestion that should be treated with skepticism, as it sounds like a way to make the state seem beneficent while actually setting itself up as a censor.

One more observation and we will have enough background to begin talking about Marconi: property rights can be considered a form of sovereignty over material goods, which is why it is possible to equate sovereignty with ownership, even though it is also possible to separate these concepts (i.e., a state can exercise authority over things it does not own). The ancient Romans distinguished between "imperium" - the power to impose rules as the governor of a territory (that is a manifestation of sovereignty) - and "dominium" - the power an owner has over his or her property (that is a manifestation of possession). [15] The ancient Egyptians were not so sophisticated in their thinking: their pharaohs were sovereigns who owned everything in their domain - every grain of sand, every peasant, every wild animal. That kind of thinking has later echoes in feudal Europe, and even later echoes in radio law.

In Honduras, for example, radio sovereignty is equated with state ownership. Article 9 of the telecommunications framework law (1995) says:

"El espectro radioeléctrico es un recurso natural de propiedad exclusiva del Estado..." [16] (The radioelectric spectrum is a natural resource which is the exclusive property of the State...)

Similarly, in Tajikistan's law of electronic communication (2002), Article 15 says:

“Радиочастотный спектр является собственностью Республики

Таджикистан." [17] (The radio frequency spectrum is the property of the Republic of Tajikistan.)

Claiming to own the radio spectrum is a more extreme position than merely claiming the right to regulate it. Yet such claims are found in the laws of many countries, apparently to reinforce the state's authority over radio by casting it as an inalienable monopoly.

\section{The origin of radio regulation}

Most people think radio regulation originated as a way to prevent interference between stations. This is not so. Early in the $20^{\text {th }}$ century, a more common argument was that only a global monopoly in radio services could reliably prevent interference. "If the air is to be used successfully by radio, it must be on the basis of a world utility, regulated by a world public service commission through agreement of the governments," wrote one prominent critic of the US Radio Act of 1927. [18] 
Gugielmo Marconi and his backers in the British and Italian governments had a similar idea although they rejected the idea of a worldwide regulatory commission. As far as I can tell, Marconi never claimed to own the radio spectrum. But he did argue that his patents were so fundamental that only his companies could transmit or receive radio waves:

"In the effort to popularize the concept of monopoly control of wireless telegraphy and to further encourage other British people to invest, wide publicity was given the progress [Marconi] made in increasing the range of the equipment.... [The] founders of the Marconi Wireless Telegraph considered that only the Marconi interests had legal rights in this field and that their patent invalidated the use of radio by others, regardless of the circuitry used... This concept did much to slow the development of radio." [19]

That's not the whole story, however, because Marconi's patents were not issued by - or recognized in - all countries. National sovereignty in the issuing of patents thus came into play as a factor hindering the creation of a global radio monopoly. [20]

Here is the real story about how radio regulation began, as told by L. S. Howeth, the US Navy's official historian of radio:

"Prince Henry of Prussia, brother of the German Kaiser, was returning to Germany, in the S. S. Deutschland, after a visit to the United States [in 1902]. Soon after sailing, he desired to send President Roosevelt a radio message

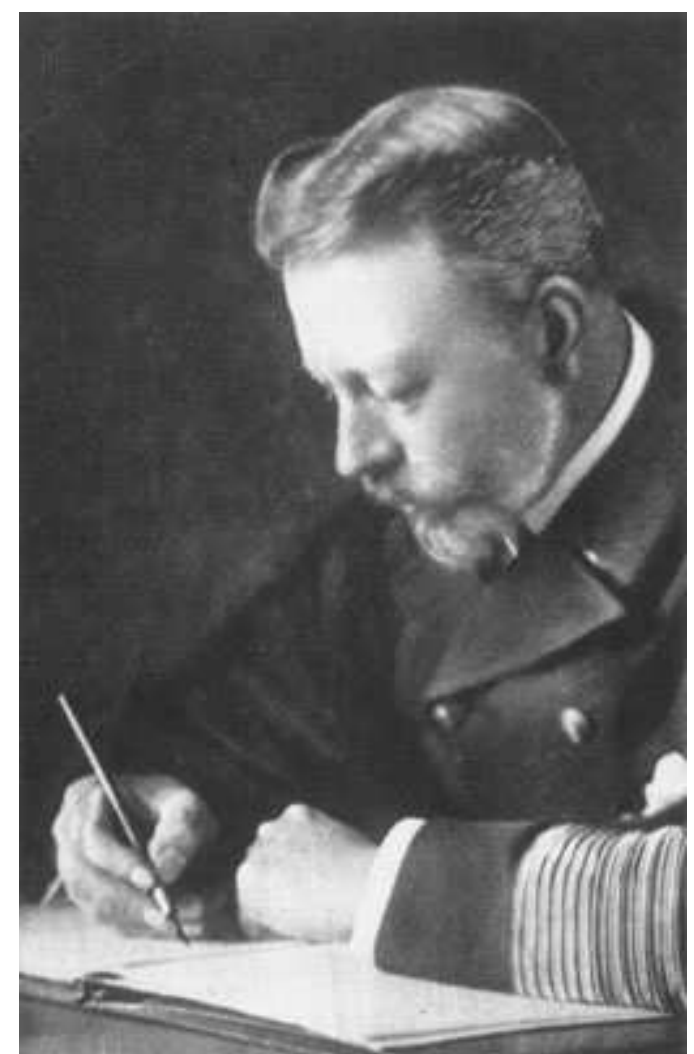

Figure 3. Prince Albert Wilhelm Heinrich (a.k.a. "Prince Henry") of Prussia

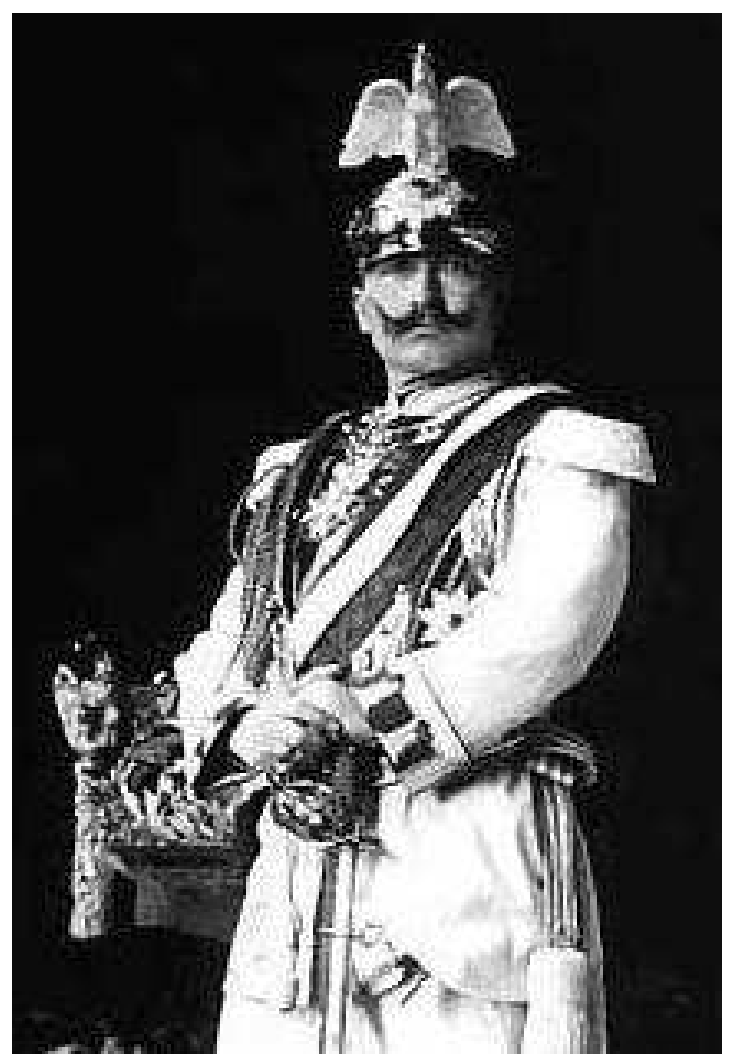

Figure 4. Kaiser Wilhelm II of Germany 
thanking him for the numerous honors and courtesies which had been accorded him. The Deutschland transmitted this message to the Marconi station at Nantucket, but that station refused to accept it because the ship was fitted with Slaby-Arco radio equipment. The irate Prince brought the matter to the attention of his brother. Kaiser Wilhelm thereupon instructed his government to initiate action in an attempt to establish international control over radio communications.” [21]

This incident - widely reported when it occurred - must be understood in the context of Marconi's business practices and the intensifying rivalry between Germany and England that would soon lead to war. The Marconi Wireless Telegraph Co. Ltd. did not sell radio equipment. If someone wanted their equipment, it could only be rented, and one also had to pay for a Marconi employee to operate the station. That gave Marconi access to the content of all radio messages as they were being sent or received. [22] His strong backing from the British Government fueled the suspicion that his operators were passing useful information to the Royal Navy, the Foreign Office, Lloyds insurance agency and similar bureaus of the Empire. [23]

In addition, his stations' refusal to "intercommunicate" with any non-Marconi station except in dire emergencies, and often not even then - looked like an attempt to freeze out competitors, although the company said it was just trying to discourage "free riders." [24] So except for Great Britain and Italy, most governments and their navies did not want to rely on Marconi for the delivery of important private messages despite the company's extensive network and acknowledged technical prowess. The rest of the world "was in no mood to accept a 'party line' arrangement in international communications." [25]

The first international radio treaty, which grew out of the 1903 Berlin conference, asserted the principle of national sovereignty in order to reign in a company many thought was abusing its dominant position in the marketplace. The treaty also required "public correspondence" stations to "intercommunicate," regardless of the type of equipment used, to reduce the largest network's advantage in attracting customers and decrease the need for duplicative stations. [26]

\section{Sea law as precedent for radio}

The first high-value application of wireless telegraphy was in ship-to-shore and ship-to-ship messaging across large bodies of water. So it was natural for people to look to sea law as a starting point for developing rules for radio.
"It may have been to radio's advantage in a purely physical sense that it came into existence during the period of intense national rivalry which preceded the...war of 19141918 , but the coincidence meant that radio became identified from the start with patriotic service to the state. No other means of communication provoked intervention by the state as quickly as did radio."

---O. W. Riegel, Mobilizing for Chaos (1934) 
Maritime law has a long history of trying to reconcile "natural law" and customs, commercial rights and risks, conflicting government policies and what is practically enforceable. Let us simplify and note that national sovereignty is only recognized in a limited range of maritime contexts: ships are subject to the jurisdiction of the country in which they are registered - and virtually all ships at sea are supposed to be registered while coastal states' sovereignty extends only to close waters (leaving seabeds out of the discussion). The seas are otherwise "open to all nations, [and] no State may validly purport to subject any part of them to its sovereignty." [27] In other words, large bodies of water are subject to two different legal regimes: territorial and extra-territorial. This partition took a long time to develop and some aspects are still controversial.

The analogy between ocean waves and radio waves seems to have been missed by the legal experts, politicians, military leaders and diplomats searching for a framework for radio regulation at the start of the last century. Had the analogy been embraced, we might have had a very different radio spectrum, with strictly limited sovereignty claims, "guard bands" around stations serving state functions and large areas open to anyone for transitory use. [28] As it is, "extra-territorial" radio in the oceanic sense hardly exists, even on the high seas or in outer space. The few exceptions are: signals from extraterrestrial intelligences (if any); clandestine broadcasts (most of which are illegal); and natural radio emissions (from astronomical objects, lightning, the Earth's magnetic field, etc.). [29]

Instead of focusing on the waves in space, the government representatives who attended the first radio conferences focused on the devices producing and detecting radio waves, their purpose, and where they were located. Location and purpose were considered dispositive. The assumption was that stations would always be either on land or on a vessel with registered nationality - in other words, in places where sea law acknowledged national sovereignty.

So analogies were found for radio in the law of the sea, but only with the locations and zones subject to state control.

The ITU is an international organization. But its purpose is not to regulate extraterritorial radio, like the International Civil Aviation Organization (ICAO) does for nonnational air spaces. The expanded role of national sovereignty in radio means that the ITU mainly provides support services for national regulators (e.g., consensus guidelines, shared databases, etc.). If the ITU is looking at ways to regulate visible light, we can be sure it is acting on behalf of national regulators. But if the "common heritage of mankind" concept had emerged earlier, the ITU's role would have been different. [30]

\section{Free as air?}

Even more than the oceans, the Earth's atmosphere used to represent something obviously beyond government control and human ownership. That changed when people began to fly.

Aviation happened to begin around the same time as radiocommunication. The first International Conference on Air Navigation took place in Paris in 1910 and, without a 
Marconi to deal with, the conferees initially seemed willing to consider a more permissive approach to airspace regulation:

"...both Germany and France advance the cause of freedom of the airspace, subject only to the safeguarding of the security of the state and its inhabitants. Britain recognized that whatever rights a state held to its superjacent airspace were restricted by freedom of passage..." [31]

But fears of surprise attacks by hostile aircraft grew quickly as international tensions mounted and airplane construction improved. Of the recognized policy options complete air freedom, state jurisdiction up to a certain altitude, sovereignty to unlimited altitudes with rights of "innocent passage" and so on - the principle of

"complete and exclusive sovereignty over national airspace [to unlimited altitudes] gained the most support in the period preceding World War I and this support culminated in the Paris Convention of 1919... Since [then], governments have slowly ceded regulatory power over the air to the international system... Over the past twenty-five years, states have begun literally to open up their skies to civil aviation with the introduction of bilateral and multilateral air agreements... But, the pace of deregulation has been painstakingly slow and much reform is needed before the aviation industry can be deemed free and global." [32]

Russia's launch of the first artificial satellite, Sputnik, in 1957 forced a rethink of national airspace as extending infinitely upward (or rather outward, since the Earth is a sphere). That could so complicate the development of space-based services that they would in effect be blocked. [33] We are fortunate it was Russia which launched the first satellites, because they could hardly argue against their own satellites' right to pass freely over other countries, even while insisting that high-altitude aircraft - U-2s, for example cannot pass freely over their country. Russia might have called for more restrictive rules for outer space if another country had beaten them into orbit. [34]

By the same token, Germany probably would not have objected to a global radio monopoly if the company seeking the monopoly had been German.

\section{Alternatives}

The need to maintain a balance of power among intensely rivalrous European countries is no longer an important consideration in global radio policy. At least it no longer provides a convincing rationale for national sovereignty to be the basis of radio regulation everywhere. It is more than strange that the concept persists without serious challenge, since it has often been noted that "radio frequencies do not respect national borders." [35]

During the past century, the institutional framework for regulating all sorts of resources has grown stronger at the regional and global levels. At the same time, new techniques and tools for automated "self-regulation" have emerged in radio, greatly reducing the need for government intervention and operator training to combat interference and ensure the efficient use of bandwidth. Furthermore, the predominant uses of radio have shifted, from high-power broadcasts from tall towers in fixed locations, and long-range missioncritical mobile communications, in which safety of life and property are at stake, to 
multitudes of short range, point-to-point links that are convenient and popular but not really necessary - e.g., cordless phones, Bluetooth, Wi-Fi, etc. The need for national governments to regulate such strictly local, personal communications is far from clear.

Here is a short and incomplete survey of alternatives to the control of radio by national governments:

- Device self-regulation: The development of fast, lightweight and cheap microprocessors has revolutionized radio design. These make it easy to build flexibility and intelligence into portable devices, as any mobile phone user knows. It never happens that when one "dials" a number on a GSM handset that one breaks into a channel already used by someone else, as was common 50 years ago with Citizen Band radio and even landline phones. Frequency assignments are made and revoked "on the fly" by the GSM network without human intervention. Frequency self-management can be expected to appear in many more wireless networks in the future. [36] Give them location awareness, a database of rules to follow, the ability to learn from experience and alter their bandwidth and modulation as needed, and human regulators would be of only marginal value.

- Regulation by real-estate owners: Even though the US Federal Communications Commission has a reputation for being among the most liberal and innovative in the world, they have always insisted on their right to preempt state and local radio regulations - and even the right of property owners to control radio use inside their premises - when these conflict with national policy objectives. [37] However, the proliferation of ultra-shortrange radio applications that work best under frequency allocations which differ from longer-range radios raises questions about the logic of national pre-emption. Noting this, J. H. Snyder recently proposed the "bundling" of local spectrum rights with tangible property rights to give property owners "dominium" over frequency use within their premises. [38]

- Regional authorities: Regional associations of national regulators have formed in all parts of the world. Their role has expanded as trade in electronic goods has globalized, increasing the need for harmonized frequency allocations and uniform equipment approval standards. WRCs being convened more regularly also demands and rewards regional policy integration. While all the regional bodies exert strong influence over spectrum policy in their geographic area, none of them issues licenses - yet. That remains the national agencies' prerogative. However, in a speech given 27 June 2006, the European Union's Commissioner for Information Society and Media, Viviane Reding, proposed replacing the national spectrum management authorities in all the states which form the EU with a single Union-level spectrum authority. [39] Her proposal met with a storm of criticism and was not even supported by other EU institutions. But she has not backed away from it and it seems compatible with historical trends. 


\begin{tabular}{|c|c|}
\hline $\begin{array}{l}\text { "Spectrum is an abstract concept } \\
\text { with no practical value" }\end{array}$ & Prior to Maxwell's explanation of electromagnetism (1873) \\
\hline $\begin{array}{l}\text { "Spectrum is a physical object with } \\
\text { no commercial value" }\end{array}$ & Research by Hertz, Popov before 1895 \\
\hline $\begin{array}{l}\text { "Spectrum is an inexhaustible } \\
\text { natural resource from which } \\
\text { everybody can profit freely" }\end{array}$ & 1901: First trans-Atlantic wireless communication \\
\hline $\begin{array}{l}\text { "Spectrum is a shared resource } \\
\text { requiring coordination among all } \\
\text { users" }\end{array}$ & 1906: First Radiotelegraph Conference \\
\hline $\begin{array}{l}\text { "Spectrum is a scarce resource that } \\
\text { must be conserved" }\end{array}$ & $\begin{array}{l}\text { 1910: First aviation radio } \\
\text { 1921: First broadcasting network } \\
\text { 1925: US Secretary of Commerce says "no more spectrum } \\
\text { available" }\end{array}$ \\
\hline $\begin{array}{l}\text { "Spectrum is regulated by an } \\
\text { intergovernmental organization and } \\
\text { partitioned into bands for separate } \\
\text { services" }\end{array}$ & $\begin{array}{l}\text { 1927: Creation of International Radio Consultative Committee } \\
\text { (CCIR) to study questions related to radiocommunication; } \\
\text { International Frequency Allocation Table covers } 10 \mathrm{kHz}-60 \\
\mathrm{MHz} \\
\text { 1932: Radio, telephone \& telegraph oversight merged to form } \\
\text { ITU } \\
\text { 1939: First commercial TV broadcast }\end{array}$ \\
\hline $\begin{array}{l}\text { "Spectrum is part of the 'common } \\
\text { heritage of mankind'; its use is to } \\
\text { be internationally registered, } \\
\text { coordinated and controlled" }\end{array}$ & $\begin{array}{l}\text { 1947: International Frequency Registration Board (IFRB) } \\
\text { created } \\
\text { 1949: ITU becomes the UN's specialized agency for } \\
\text { telecommunications } \\
\text { 1957: First artificial Earth satellite } \\
\text { 1958: First data transmission via satellite }\end{array}$ \\
\hline $\begin{array}{l}\text { "Global communications are } \\
\text { enhanced by adding the } \\
\text { geostationary satellite orbit to the } \\
\text { spectrum resource" }\end{array}$ & $\begin{array}{l}\text { 1963: First World Space Radiocommunication Conference } \\
\text { 1965: First commercial communication satellite } \\
\text { 1978: First wireless public phone }\end{array}$ \\
\hline $\begin{array}{l}\text { "In some countries, spectrum is a } \\
\text { commodity which can be bought } \\
\text { and sold" }\end{array}$ & $\begin{array}{l}\text { 1989: New Zealand authorizes tradable spectrum rights } \\
\text { 1995: US spectrum auction sets record price: } \$ 258 \text { million per } \\
\text { MHz }\end{array}$ \\
\hline $\begin{array}{l}\text { "The private sector is invited to } \\
\text { participate in international } \\
\text { regulatory processes" }\end{array}$ & 1995: ITU membership open to non-governmental entities. \\
\hline $\begin{array}{l}\text { "Privatize spectrum \& orbital } \\
\text { resources? Free markets for } \\
\text { spectrum \& orbital slots? }\end{array}$ & $\begin{array}{l}\text { Now: "Information Society" concept; Digital switchover in } \\
\text { television; constellations of Low-Earth-Orbit satellites; High- } \\
\text { Altitude Platforms; proliferation of wireless data networks and } \\
\text { license-exempt short-range devices; Ultra-wideband; } \\
\text { "Cognitive" and "software-defined" radio }\end{array}$ \\
\hline
\end{tabular}

Figure 5. The radio spectrum's evolving character, with historical milestones (inspired by and adapted from Struzak [see note 7]) 


\section{Conclusion}

An emphasis on national sovereignty as the basis of radio regulation goes back to the industry's earliest days, when "radio" was synonymous with "wireless telegraphy." This principle had also shaped Europe's approach to wire telegraphy [40] and following its use in the law of the sea seemed apt since maritime communication was wireless telegraphy's first major application. National sovereignty in patent law was already hindering Marconi's quest for a global monopoly, so it was an obvious instrument for reigning in a company perceived as abusing its market dominance. Without a Marconi, the more relaxed attitude that European countries initially displayed toward air space sovereignty in the same time-frame might also have arisen in radio. But we cannot know that for sure.

Enough technical experts saw monopoly as a good way to prevent interference between stations that it probably wasn't a Marconi monopoly which bothered people so much as the firm's business practices and its close ties to the British Government. Adding a monopoly in wireless telegraphy to Great Britain's "virtual monopoly" in submarine cables [41] and dominance at sea would have ended even the pretense of a balance of power in Europe.

The law of the sea offered a precedent for limiting claims of national sovereignty but the early radio conferences ignored that feature. On the other hand, designating the radio spectrum as a "common heritage of mankind" might have achieved as much control over the Marconi company as claims of national sovereignty - perhaps even more. This concept was known to at least a few diplomats by 1912, but at the time there was no international organization capable of fairly regulating access to the radio spectrum and trying to establish one anyway would have been dangerous.

Looking back, it is obvious that the need for government intervention in radio came from shortcomings in the early technology - as well as the political, economic and military considerations discussed above - rather than from the character of electromagnetic waves themselves. Before microprocessors were incorporated into radio design, the sources of signals propagating through space were simply too "dumb" to recognize and avoid each other's transmissions, thus producing interference. But "smart" radios can identify empty channels, avoid occupied ones, and utilize no more electro-space than is needed for a specific application. It is clear that most radios will soon be capable of managing their communications automatically, without the need for state intervention. And apart from self-regulation, the possibility of successful regulation at the local and regional levels suggests that the time has come to bring the era of radio regulation based on national sovereignty to a close - before it expands into the domain of visible light.

\section{NOTES}

[1] Some of these claims are documented on the "country" pages of the Open Spectrum Foundation's website, http://www.openspectrum.info/.

[2] Most of this treaty is online at the website of the ITU's Amateur Radio Club - http://life.itu.int/radioclub/ rr/rrcont.htm

[3] On 5 February 1897 the Indiana House of Representatives approved bill number 246, which declared that in Indiana the "ratio of the diameter and circumference [of a circle] is as five-fourths to four." The phrase 
"a new mathematical truth" comes from the legislation's statement of purpose. Voting on this bill in the Indiana Senate was postponed indefinitely, so it is still pending legislation. See http://www.agecon.purdue.edu/crd/Localgov/Second\%20Level\%20pages/indiana_pi_bill.htm

[4] Henning Genz, Nothingness: The Science of Empty Space (Cambridge, Massachusetts USA: Perseus Publishing, 2001), page 189. Originally published in 1994 in German as Die Entdeckung des Nichts by Carl Hanser Verlag (Vienna, Austria).

[5] The public debut of the "common heritage of mankind" as a legal framework for natural resources is generally credited to Arvid Pardo, Malta's ambassador to the UN. In a 1967 speech to the UN General Assembly, he argued that "an effective international regime over the seabed and the ocean floor beyond a clearly defined national jurisdiction [is] the only alternative by which we can hope to avoid the escalating tension that will be inevitable if the present situation is allowed to continue." The "present situation" to which he referred was the expansion of competing claims of national sovereignty made by coastal countries over oceanic resources in the decades following World War 2 - to gain control of resources that had previously been regarded as belonging to no one. Defining these resources as the "common heritage of mankind" was intended to put them beyond claims of national sovereignty. See "United Nations Convention on the Law of the Sea of 10 December 1982: Overview and full text" - http://www.un.org/ Depts/los/convention agreements/convention overview convention.htm..

[6] "A thorough look at the archives of the library of the Palais des Nations in Geneva will reveal that it was in the Outer Space committee, and not in the Seabed and Ocean Floor committee that the expression [common heritage of mankind] was used and explained for the first time." Quoted from "The Law of Outer Space and Natural Resources," by Sylvia Maureen Williams, International and Comparative Law Quarterly, Vol. 36, No. 1 (January 1987), page 145 - http://www.journals.cambridge.org/action/displayIssue?jid=ILQ $\underline{\text { \&volumeId}=36 \& \text { issue } I d=01 \#}$

[7] See, for example: "State Sovereignty and the Effective Management of a Shared Universal Resource: Observations Drawn from Examining Developments in the International Regulation of

Radiocommunication," by Donald J. Fleming, E. D. DuCharme, Ram S. Jakhu and W. G. Longman, Annals of Air and Space Law, Vol. X (1985), pages.326-352; "The Commons in the Sky: The Radio Spectrum and Geosynchronous Orbit as Issues in Global Policy," by Marvin S. Soroos, International Organization, Vol. 36, No. 3 (Summer, 1982), pages 665-677 - http://links.jstor.org/sici?sici=00208183(198222)36\%3A3\%3C $665 \% 3 \mathrm{ATCITST} \% 3$ - E2.0.CO\%3B2-0; or "Introduction to International Radio Regulation," by Ryszard Struzak (Trieste, Italy: Abdus Salam International Centre for Theoretical Physics, 2003) http://users.ictp.it/ pub_off/lectures/lns016/Vol_16.pdf.

[8] See, for example, “'Propertyzing' the Electromagnetic Spectrum: Why It's Important, and How to Begin," by Lawrence J. White, Media Law and Policy, Vol. IX, No. 1 (Fall, 2000) - http://www.stern.nyu.edu/ eco/wkpapers/workingpapers00/00-08White.pdf, "An Experiment in Airwave Ownership: Spectrum Liberalization in Guatemala," by Thomas Hazlett and Giancarlo Ibarguen, presented at the 2002 meeting of the Association for Private Enterprise Education (Cancun, Mexico, 9 April 2002) -

http://mason.gmu.edu/ thazlett/pubs/An_experiment.pdf. An enjoyable critique of the propertyizing agenda is found in Lawrence Lessig's "Deregulating Spectrum" (February 2007), a 27-minute narrated video slideshow - http://www.lessig.org/blog/archives/Spectrum_small.mov

[9] World Radiocommunication Conferences (WRCs) are convened about every 3 years by the ITU to consider changes to the International Radio Regulations, to the Recommendations which guide national regulatory authorities, and to the Questions that set the ITU technical study groups' agendas.

[10] Article 1 of the 2004 revision of the International Radio Regulations defined "radio waves" as "Electromagnetic waves of frequencies arbitrarily lower than $3000 \mathrm{GHz}$, propagated in space without artificial guide." - http://life.itu.int/radioclub/rr/art01.htm

[11] The ITU Plenipotentiary Conference in 2002 decided - in Resolution 118 - to extend the ITU's administrative mandate into the realm of visible light by allowing future WRCs to include in their agendas items dealing with the regulation of frequencies above $3000 \mathrm{GHz}$. WRC-07's resolution on the regulation of optical frequencies is an early and direct result of that decision. See "Resolution COM6/9 (WRC-07): Consideration of procedures for free-space optical links," in World Radiocommunication Conference Provisional Final Acts, Geneva, 22 October - 16 November 2007, pages 460-1.

[12] http://en.wikipedia.org/wiki/Sovereignty

[13] ibid. 
[14] The Freedom of the Seas, or the Right which Belongs to the Dutch to Take Part in the East Indian Trade, by Hugo Grotius, translated from Latin to English by R. V. D. Magoffin (Oxford University Press, 1916), reprinted by Batoche Books Ltd. (2000) - http://socserv2.mcmaster.ca/ econ/ugcm/3113/grotius/Seas.pdf . This treatise - whose Latin title is usually shortened to Mare Liberum - had a major role in limiting national rights and state jurisdiction over the oceans and establishing rights of free navigation and transit during the $17^{\text {th }}$ century.

[15] "Fundamental Concepts of the Roman Law," by Max Radin, California Law Review, Vol. 12, No. 5 (July 1924), pages 393-410 - http://links.jstor.org/sici?sici=0008-1221(192407)12\%3A5\%3C393\%3AF COTRL\%3E2.0.CO

[16] Republic of Honduras, "Ley Marco del Sector de Telecomunicaciones," Decreto No. 185-95 (1995) y Decreto No. 118-97 (1997) - http://www.conatel.hn/LEY_MARCO_TELECOMUNICACIONE.HTM:

[17] Republic of Tajikistan, “Закон Республики Таджикистан «Об электрической связи»” (2002) http://medialaw.ru/exussrlaw/l/tg/svyaz.htm

[18] Quote from “Department of Current Legislation: The Radio Act of 1927," by Joseph P. Chamberlain, American Bar Association Journal, Vol. 13 (1927) page 343, cited in "A Desperate Case Under the Commerce Clause: Federal Jurisdiction Over All Radio Use," by Douglas A. Galbi (2002), page 5 http://ssrn.com/abstract=352361.

[19] Quoted from History of Communications-Electronics in the United States Navy, by Linwood S. Howeth (Washington, DC USA: US Government Printing Office, 1963), page 20 - http://earlyradiohistory.us/ 1963hw02.htm

[20] On the territoriality of patent law and how it interacts with local conceptions of the public domain, see "The Public Domain and International Intellectual Property Law Treaties," by Antony Taubman, in Intellectual Property: The Many Faces of the Public Domain, edited by Charlotte Waelde and Hector MacQueen (Cheltenham and Camberley, United Kingdom: Edward Elgar Publishing Ltd., 2007) http://ssrn.com/abstract=1010527.

[21] Howeth, page 71. Lest there be any doubt that it was Marconi's business practices and monopoly ambitions that precipitated radio regulation, here is an account by the ITU's historian:

"The aim of the German Government in calling the [first international conference on radio] was clear from the beginning. The chief of the German delegation, and president of the Conference, in his opening remarks stated that the development of radio, which was still in its infancy, would be unduly hampered by any attempt to monopolize facilities and that, therefore, rules should be made to block any attempt to impose one system upon others. His attack was made directly at the Marconi Company, and the Marconi Company's restrictive practices were cited as an example of an attempt to force one system on all the world."

Quoted from The International Telecommunication Union: An Experiment in International Cooperation by George A. Codding Jr., (New York, NY USA: Arno Press, 1972, reprint of the E. J. Brill edition, 1952), page 84 .

[22] Apparently, Marconi did try at first to sell his radio equipment. "But because the operation of the equipment required well-trained personnel, Marconi was not very successful with this business model. Commercial success began when the Marconi Company decided to rent their equipment (including trained operators) to shipping companies and to practice a nonintercommunication policy." Quoted from "The Beginnings of Radio Communication in Germany, 1897-1918," by Michael Friedewald, Journal of Radio Studies, Vol. 7, No. 2 (2000), pages 441-463 - http://www.leaonline.com/doi/pdfplus/10.1207/s15506843 jirs0702 15.

[23] "Marconi receiving stations, British Post Office stations, and an Admiralty 'police' station all provided intercepts for [British Naval Intelligence]... The British Secret Service also took to putting its agents aboard merchant ships as Marconi wireless operators, when particular ports of call were of interest..." Quoted from Radio Spies: Episodes in the Ether Wars by Bartholomew Lee $(2002,2006)$ - http://www.trft.org/ TRFTP ix/spies9eR2006.pdf. By the end of September 1914, the Marconi Company was operating 10 secret stations devoted to wireless communications interception for the British Navy, according to Nigel West's SIGINT Secrets: The Signals Intelligence War, 1900 to Today (New York, USA: William Morrow and Company, 1988), page 45. 
[24] For a contemporary defense of Marconi's most-criticized business practices, see "Letter to the Editors: Mr. Marconi and His Critics," by Wilfrid Blaydes, Electrical World and Engineer, 12 April 1902, pages 656658 - http://earlyradiohistory.us/1902ew.htm

[25] Mobilizing for Chaos: The Story of the New Propaganda by O. W. Riegel (New Haven, CT USA: Yale University Press, 1934), page 34. "Party line" is an old telephone term for a shared line in which either party can listen secretly to the other's conversations.

[26] "International Radio Telegraph Convention of Berlin: 1906" (Washington, DC, USA: Government Printing Office, 1912) - http://www.itu.int/ITU-R/information/promotion/100-years/documents/1906Berlin-E.pdf

[27] Quoted from Article 2 of the "Convention on the High Seas" (1958) - http://untreaty.un.org/ilc/texts/ instruments/english/conventions/8_1_1958_high_seas.pdf.

[28] Of course, the purpose of maritime law is not to control the behavior of waves. That may be why this analogy did not seem useful. For a very different set of water/radio analogies, see "Of Rainbows and Rivers: Lessons for Telecommunications Spectrum Policy from Transitions in Property Rights and Commons in Water Law," by Dale B. Thompson, Working Paper No. 21, William Mitchell College of Law (July 2005) - http://ssrn.com/abstract=770426

[29] There are radio transmitters carried by weather balloons through the upper atmosphere - "radiosondes" - as well as radios permanently anchored or drifting on the high seas - "radio buoys." But all of these are either government controlled navigation aids, research programs directed by governments or sponsored by academic institutions subject to national laws. Similarly, transmitters in orbit or outside the Earth's atmosphere are all owned by specific nations or by international organizations whose members are sovereign countries. Clandestine broadcasting stations whose locations and sponsors are unknown are the closest we get to "extra-territorial" radio produced by humans. These include insurgent political projects like "Sowt Alamel," an anti-Qadaffi station thought to be hidden in the Egyptian or Libyan desert; and shortwave "numbers stations" which are believed to be operated by intelligence agencies to send their spies coded messages. Unlicensed broadcasting of pop music from ships moored in international waters was a major commercial activity in Europe in the 1960s. Great efforts were made to suppress it. That can be considered "extra-territorial radio," too. See "Pirate Broadcasting in European Waters," by Neville March Hunnings, International \& Comparative Law Quarterly, Volume 14, Issue 02, (April 1965), pages 410-436 - http://www.journals.cambridge.org/action/ displayIssue?jid=ILQ\&volumeId=14\&issueId=02\#; Clandestine Radio Broadcasting: A Study of Revolutionary and Counterrevolutionary Electronic Communication, by Lawrence C. Soley and John C. Nichols (New York, NY USA: Praeger Publishers, 1986); "Numbers Station," Wikipedia - http://en.wikipedia.org/wiki/Numbers station; "Radiosonde Radio Spectrum Issues," by D. Franc, World Meteorological Organization Commission for Instruments and Methods of Observation, Expert Team on Upgrading the Global Radiosonde Network (November 2003) http://www.wmo.ch/pages/prog/www/IMOP/meetings/Upper-Air/Radiosonde-netw/Doc5-2.pdf; 'The Status, Development and Future Role of Radiobeacon Differential Global Navigation Sounding Systems," by N. Ward, Journal of Navigation, Vol. 51 (1998), pages 152-158 - http://journals.cambridge.org/action/ displayAbstract?fromPage $=$ online $\&$ aid $=37853$

[30] Strictly speaking, the ITU could not have supervised the spectrum under a "common heritage of mankind" regime even if the early radio conferences had mandated it. The first radio treaty established the International Radio Telegraph Union, but that was just a group of countries stating their agreement on some basic principles. The IRTU did not become an organization with a permanent staff and budget until just before it merged with the International Telegraph Union to form the International Telecommunication Union in 1932. At the dawn of radio regulation, there simply was no institution that could have managed the spectrum, impartially and globally, for humanity.

However, during the COMMUNIA workshop, Philippe Aigrain pointed out that the concept of a "common heritage of mankind" was first used in a diplomatic context as early as 1912, though this was not wellknown at the time or even subsequently. According to Daniel Bardonnet's historical analysis in René-Jean Dupuy's anthology Humanité et droit international (Paris, France: Pedone, 1991), a draft convention produced by the Christiana Conference on the status of the Spitzbergen Archipelago (near Greenland) suggested that these islands might be designated as "patrimoine commun de l'humanité" because of their unique value in polar research. See "René-Jean Dupuy: Une ouvre au service de l'humanité" (Paris, France: UNESCO, 1998), page 110 - http://unesdoc.unesco.org/images/0011/001177/117755fo.pdf. So it is not farfetched to suppose that the same concept could have been applied to the radio spectrum if it had emerged a few years earlier. 
[31] The Struggle for Law in the Age of Air Power, by Edward L. McNally (1952), page 5 http://www.documeant.net/Portfolio/struggle4law.pdf

[32] "Freedom of the Skies: International Law and the Aviation Industry," by Alexander Parets (no date) http://www.anselm.edu/NR/rdonlyres/CFA16C8E-F103-4C2C-B362-B89BBF98842F/10916/final ParetsPDF.pdf

[33] Like the boundary between heat and radio, the boundary between air space and outer space is "soft." See, for example, The Never Ending Dispute: Delimitations of Air Space and Outer Space by Robert F. A. Goedhart (Singapore: Editions Frontières, 1996); "Outer Space and Air Space: The Difficulties in Definition," by Raymond J. Barrett, Air University Review, May-June 1973 http://www.airpower.maxwell.af.mil/airchronicles/aureview/1973/may-jun/barrett.html

[34] For an account of how "open skies" and "freedom of outer space" policies emerged in the 1950s from national security considerations in the US, see "Tinker, tailor, satellite, spy," by Dwayne A. Day, The Space Review (October 2007) - http://www.thespacereview.com/article/989/1

[35] Quoted in this instance from "How ITU processes and regulations have helped shape the modern world of radiocommunications," by Valery Timofeev, ITU News Magazine, issue 3/2006 - http://www.itu.int/ itunews/manager/display.asp?lang=en\&year=2006\&issue=03\&ipage=radiotelegraphy\&ext=html

[36] "Spectrum Management: The Killer Application of Ad Hoc and Mesh Networking," by John A. Stine, The MITRE Corporation, October 2005 - http://www.mitre.org/work/tech_papers/tech_papers_05/ 05 1166/05 1166.pdf ; "Cognitive Radio, Spectrum and Radio Resource Management,” by Working Group 6 of the Wireless World Research Forum (2004) - http://www.wireless-world-research.org/ fileadmin/sit es/default/files/about the forum/WG/WG6/White\%20Paper/WG6_WP4.pdf; "In Pursuit of a Wireless Device Bill of Rights," by Kalle R. Konston, presented at the Spectrum Management Working Group of the FCC's Technological Advisory Council, 18 September 2002 - http://www.fcc.gov/ realaudio/presentati ons/2002/091802/bill_of_rights.ppt

[37] See, for example, "The development of wireless telecommunications and local governments' policy responses: The U.S. case," by Seongcheol Kim, Government Information Quarterly, Vol. 24, Issue 3 (July 2007), pages 611-623 - http://www.sciencedirect.com/science? ob=ArticleURL\& udi=B6W4G4N55TGF-1\&_user=10\&_rdoc=1\&_fmt=\&_orig=search\&_sort=d\&view=c\&_acct=C000050221 \&_version=1\&_urlVersion $=0$; on the FCC's preemption of local rules for receiving antennas, see "Information Sheet: Over-the-Air Reception Devices Rule," US Federal Communications Commission (December 2007) - http://www.fcc.gov/mb/facts/otard.html; for the FCC's right to preempt property owner rules restricting tenant use of Wi-Fi, see "Memorandum Opinion and Order In the Matter of Continental Airlines Petition...” (ET Docket No. 05-247), FCC decision adopted 17 October 2006 http://hraunfoss.fcc.gov/edocs_public/attachmatch/FCC-06-157A1.pdf

[38] "Spectrum Policy for the Emerging Ultrabroadband World: Should Spectrum and Tangible Property Rights Be Bundled?" by James H. Snider, presented at a conference on "Ultrabroadband Networks and the Personal Media Cloud," Columbia University Institute for Tele-Information (New York, 22 June 2007) http://www.newamerica.net/files/SniderCITIPaper_SpectrumPolicyForEmergingUltrabroadbandWorld.pdf

[39] "The Review 2006 of EU Telecom rules: Strengthening Competition and Completing the Internal Market," text of a speech given by Viviane Reding, Member of the European Commission responsible for Information Society and Media at the Annual Meeting of BITKOM (Brussels, 27 June 2006) http://europa.eu/rapid/pressReleasesAction.do?reference=SPEECH/06/422\&format=HTML\&aged=0\&lang $\underline{\text { uage }=\text { EN\&guiLanguage }=\text { en }}$

[40] “...governments across Europe built state owned telegraph networks during the 1850s. Most - but not all were granted monopoly rights... [A] crucial aspect of the European approach was that when a state did not monopolize telegraphy, the concessions they awarded went only to domestic firms. As a foreigner, even Morse was excluded in the countries where he had a patent." Quoted from "Media Licensing, Convergence and Globalization" by Robert Horvitz, EastBound, Vol. 1 (March, 2006) - http://ssrn.com/abstract=895060

[41] "The emergence of Great Britain during the nineteenth century as the major factor in [undersea] cable communication was also due to the British monopoly of gutta-percha, used for cable insulation... Great Britain negotiated with other powers and obtained concessions in cable laying which gave her virtual monopoly in this industry..." Quoted from Riegel, pages 21-22. 